\title{
Iron Overload and Insulin Resistance in a Sample of Turkish Patients with Non-Alcoholic Steatohepatitis
}

\author{
Türk Toplumu Örnekleminde Alkole Bağlı Olmayan Steatohepatit Hastalığının Demir Yüklenmesi ve Insülin
} Direnci ile ilișkisi

\author{
Hale Gökcan'1, Yasemin H Balaban², Halis Șimșek³, Engin Yılmaz', Gökhan Gedikoğlu5 \\ Gülsen Hasçelik6 ${ }^{6}$ Gonca Tatar ${ }^{3}$
}

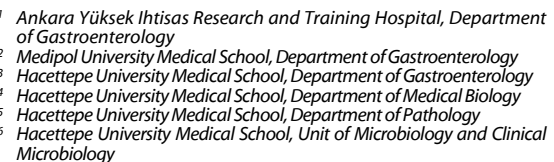

Received : May 03,2015 • Accepted: Sep 07,2015

\section{Corresponding Autho}

Hale Gokcan, M.D.

Tel: +903123061000

Fax: +903123124120

E-mail: halesumer@yahoo.com

Ankara Yüksek Ihtisas Research and Training Hospital,

Department of Gastroenterology

Atatürk Bulvarı Kızılay Sokak No:4 Sınhiye - Ankara PC: 06100

Amaç: Bu çalıșmada alkole bağlı olmayan steatohepatit (NASH) tanısı olan hastalarda H63D mutasyonunun demir yüklenmeși ve karaciğer hasarı üzerindeki etkisi; insülin direnci ve metabolik sendrom ile ilișkisi araștırıldı.

Yöntem ve Gereçler: Hacettepe Üniversitesi, Gastroenteroloji polikliniğinde klinik ve laboratuar olarak NASH tanıs alan 32 hasta çalıșmaya alındı. Hastalar metabolik sendrom açısından sorgulandı. Bel kalça oranı ve vücut kitle indeksleri hesaplandı. H63D gen mutasyonu, serum ve karaciğer dokusunda demir parametreleri ve boyanması; karaciğer histopatolojik özellikleri incelendi. İnsülin direnci ve metabolik sendrom ile ilișkili olarak açlık ve tokluk kan sekeri, lipid profili, 75-gr oral glukoz tolerans testi ve HOMA insulin direnci hesaplaması yapıldı.

Sonuç: Ortalama vücut-kitle indeksi (VKi) $28,1 \pm 33 \mathrm{~kg} / \mathrm{m}^{2}$ olan 32 hasta çalıșmaya alındı. Hipertansiyon (\%25), obezite (\%37), hiperkolesterolemi (\%56), hipertrigliseridemi (\%28) ve insülin direnci (\%39) oldukça sıktı. İi hasta hariç tüm hastaların ferritin ve transferrin saturasyonu normaldi. Hastaları \%41'inde HIC $1600 \mu \mathrm{g} / \mathrm{g}^{\prime} ı$ in üzerinde saptandı. H63D mutasyonu $12(\% 40)$ hastada heterezigot, $1(\% 3)$ hastada ise homozigot saptandı. NASH hastalarında H63D alel frekansı \%23,4 idi (\%3,3 homozigot, \%20 heterozigot). H63D mutasyonu olan hastalarda serum ve doku demir belirteçleri normal idi. H63D mutasyonu ile histopatolojik bulgular arasında ilișki saptanmadı. 2. saat kan șekeri ölçümü evre 2 fibrozisi olan hastalarda evre 1 olan hastalara göre, sınıf 4 hastalarında sınıf $\leq 3$ olan hastalara göre istatistiksel olarak yüksek saptandı.

Sonuç: H63D mutasyonunun serum demir belirteçlerine veya histopatolojiye etkisi saptanmadı. Bununla birlikte non-alkolik steatohepatit hastalarında insülin direnci fibrosis ile ilișkili bulundu.

\section{Anahtar Sözcükler: HFE, H63D Mutasyonu, Non-Alkolik Steatohepatit, Demir Yüklenmesi, insülin Direnci}

Aim: We investigated the role of the H63D mutation on the development of hepatic iron overload and hepatic injury in non-alcoholic steatohepatitis patients and its association with insulin resistance and metabolic alterations.

Material and Methods: Thirty-two patients with NASH, who were diagnosed at Hacettepe University Gastroenterology Outpatient Clinic depending on clinic and laboratory findings, were included into study. Metabolic syndrome was sought. Waist hip ratio and body mass index were calculated. H630 gene mutation, iron level at serum and liver biopsy specimens and histopathologic exam on liver biopsy specimens were studied in study group. Fasting and post-prandial blood sugar, lipid profile, 75-gr-glucose tolerance test and HOMA insulin resistance were measured to document the insulin resistance and metabolic syndrome.

Results: Thirty-two patients with mean body mass index was $28.1 \mathrm{~kg} / \mathrm{m}^{2} \pm 3,3$ were included in study. Hypertension, obesity, hypercholesterolemia, hypertriglyceridemia, insulin resistance were found at $25 \%, 37 \%, 56 \%, 28 \%$ and 39 $\%$, respectively. Serum ferritin and transferrin saturation values were within normal limits in all but except 2 patients. Hepatic iron concentration was $>1600 \mu \mathrm{g}$ in $12(41 \%)$ of patients. H63D mutation was homozygote in $1(3 \%)$ and heterozygote $12(40 \%)$ patients. Therefore the H63D allele frequencies were $3.3 \%$ for homozygous, $20 \%$ for heterozygous and as total $23.4 \%$. The patients with H63D mutation had normal serum and tissue iron parameters. There was no statistically significant relationship between H63D mutation and histopathological findings. Two hour blood sugar levels were higher in Stage 2 patients than in Stage 1 patients $(p=0.05)$, and also higher in Class 4 patients than in Class $\leq 3$ patients $(\mathrm{p}=0.05)$.

Conclusion: The H63D mutation did not affected either serum iron parameters or histopathology. However, the insulin resistance was related with fibrosis in non-alcoholic steatohepatitis patients.

Key Words: HFE; H63D Mutation, Non-Alcoholic Steatohepatitis, Iron Overload, Insulin Resistance

Non-alcoholic fatty liver disease (NAFLD) is a necroinflammatory disease of the liver characterized by fat infiltration in the hepatocytes of subjects without excessive alcohol consumption, and may present a wide spectrum reaching from simple steatosis to steatohepatitis, fibrosis, and cirrhosis. Non-alcoholic steatohepatitis (NASH) is characterized by macrovesicular steatosis, and lobular inflammation and/or Mallory bodies, fibrosis and cirrhosis. Although NASH was initially described as a benign clinical presentation, it is now acknowledged to potentially progress to fibrosis, cirrhosis and terminal liver disease. 
The prevalence of NAFLD is uncertain due to the silent progression, the unspecified natural course and the lack of consensus regarding the histological diagnosis. NAFLD is a common disease worldwide, and ethnic prevalence is unclear (1). However, the prevalence of NAFLD, $10-15 \%$ in non-obese individuals, may escalate up to 70 $80 \%$ in obese subjects. The frequency of NASH, on the other hand is 2.7$3 \%$ in non-obese and $15-20 \%$ in morbidly obese individuals (2). NAFLD is observed in all age groups, including children (3). Its prevalence increases between the ages $40-49$ (in the $4^{\text {th }}$ decade) $(4,5)$. Initially, NASH was believed to be more prevalent in women $(53-85 \%)$ $(4,, 6)$; the current conviction is that prevalence in men and women are similar, or even higher in men (7). $\mathrm{NASH}$ may co-exist with diabetes mellitus (DM), hyperlipidemia, hypertension and obesity. NAFLD may be considered the hepatic component of metabolic syndrome $(8,9)$. The pathogenesis of NASH is considered to be a 2-step process: While there is excessive fat accumulation in the liver in the first step, oxidative stress, hepatocyte necrosis, stellate cell activation dependent fibrosis and cirrhosis develop in the second stage. Insulin resistance and hyperinsulinemia constitute the primary anomaly in NAFLD. Hepatic fibrosis is progressive in some NASH patients, leading to liver failure. In these patients, iron accumulation in the liver and HFE mutations and iron accumulation in the liver are independent risk factors for hepatic fibrosis. Current knowledge about the prevalence of HFE mutation and its effects on hepatic iron accumulation and fibrosis in NASH patients is controversial. In hereditary hemochromatosis $(\mathrm{HH})$ patients, besides studies that demonstrate a higher prevalence of $\mathrm{C} 282 \mathrm{Y}$ and H63D mutations that lead to iron overload, tissue destruction and organ failure in NASH patients compared with the normal population, there also exist studies that report no association between iron overload, HFE mutation and fibrosis (10-12). This study aimed to investigate the prevalence of H63D mutation and iron load of liver in association with insulin resistance and metabolic alterations in NASH patients. Since, we have previously shown that C282Y mutations are sparse in Turkish population, therefore, patients with a diagnosis of $\mathrm{NASH}$ were tested for H63D mutations, but not $\mathrm{C} 282 \mathrm{Y}$ mutations in this study (13-15).

\section{MATERIAL AND METHODS}

\section{Clinical Characteristics}

The informed consent form was approved by the Hacettepe University Ethics Committee and signed by all the patients prior to study entry. Patients with elevated liver enzymes and presenting to our gastroenterology department were screened. The exclusion criteria were age under 17 years or over 70 years, Diabetes Mellitus, drugs or alcohol consumption, viral hepatitis, autoimmune hepatitis, Wilson disease, alfa1-antitrypsin deficiency, hereditary hemochromatosis, cryptogenic cirrhosis, malignancy, collagen tissue disease, previous gastrointestinal system surgery, obstructive type jaundice. The physical examination included waist and hip circumferences, body height and weight, and blood pressure measurement. The waist to hip ratio (WHR) and body mass index (BMI) were calculated. Cutoff value for WHR was taken as 0.9 (16).

The patients with clinical and laboratory signs of NASH had a diet and exercise program for 3 months. Those patients with normal or less than 1.3 fold increased alanine transaminase (ALT) level following the diet and exercise program, and those unable to attend follow-up visits were also excluded.

Laboratory tests included ALT, aspartate aminotransferase (AST), alkaline phosphatase (ALP), gammaglutamyltransferase (GGT), total bilirubin, albumin, cholesterol, triglycerides (TG), high-density lipoprotein (HDL), low-density lipoprotein (LDL), $\mathrm{C}$ reactive protein (CRP), fasting blood glucose, serum iron, iron-binding capacity, ferritin, apolipoprotein A1 (apoA1), apolipoprotein B (apoB), lipoprotein a $\quad[\mathrm{lp}(\mathrm{a})], \quad$ ceruloplasmin, $\quad \alpha 1$ antitrypsin ( $\alpha 1 \mathrm{AT})$, and copper $(\mathrm{Cu})$ excreation in 24-hour urine. The AST/ALT ratio and transferrin saturation (TS) (serum iron/total iron-binding capacity) were calculated. A standard 75-gr oral glucose tolerance test (OGTT) was performed on patients during whom the measurement of blood glucose was done at hour 0,2. Patients with a 2-hour blood sugar of $\geq 140$ were considered to have impaired glucose tolerance (IGT). The fasting insulin and $\mathrm{C}$ peptide levels were also measured. The homeostatic model assessment (HOMA) index [(fasting insulin $(\mu \mathrm{U} / \mathrm{ml}) \times$ fasting blood sugar (mmol/l) / 22.5] was calculated (17). Different cut off values for HOMA (range 2-3) are defined in various studies. We set the HOMA cut off value as "HOMA $>$ 3" for investigating insulin resistance; as higher cut off value provides higher level of specificity for insulin resistance (18).

\section{Histopatological Evaluations}

Thirty-two patients meeting these criteria underwent liver biopsy for definite diagnosis of NASH and quantitative analysis of liver iron load. The classification system defined by Brunt et al. (19) was used for histopathological staging and grading. Liver biopsies were graded between 1 and 3 according to the degree of portal inflammation (none, mild, mild-moderate), type of steatosis (macrovesicular, microvesicular or mixed type), degree of steatosis (<33\%, 33-66\%, >66\%), ballooning (present, absent), and lobular inflammation (present, absent). The liver fibrosis was categorized from Stage 1 to 4. The method of Mac Sween et al. (20) was used for iron staining of the liver tissue. Iron concentration was measured in the dry liver tissue (HIC $\mu \mathrm{g} / \mathrm{g}$ ) and 
hepatic iron index (HII) was calculated $(\mu \mathrm{mol} / \mathrm{g} /$ age $)(21)$. Patient with HIC levels of $>1600 \mu \mathrm{g} / \mathrm{g}$ or HII 1.1-1.9 was accepted to have iron overload (22). Patient with HIC levels of $>3000 \mu \mathrm{g} / \mathrm{g}$ or $\mathrm{HII}>1.9$ was defined as $\mathrm{HH}$ and excluded from the study.

\section{Mutation Analysis}

In a previous study we searched the frequency of HFE mutations on $\mathrm{HH}$ patients and healthy blood bank donors and we did not find any C282Y mutations, but found a $21,05 \%$ allele frequency for H63D mutation in healthy blood bank donors. Therefore only H63D mutation was tested in this study, as C282Y mutation was not shown in Turkish population. The previously calculated H63D allele frequency $(21.05 \%)$ from 57 healthy blood bank donors was taken as the expected allele frequency for the current study (\%21.05) (13).

DNA samples analysis were isolated from the 10-ml peripheral blood obtained from 32 NASH patients by the salt settling method and stored at $-20^{\circ} \mathrm{C}$ until use. Sau $3 \mathrm{AI}$ restriction endonuclease enzyme was used for H63D mutation analysis. This enzyme procures DNA cleavage via recognition of the GATC sequence. For the analysis 15 ul DNA, reproduced by PCR, was incubated with 10 units of the enzyme at $25^{\circ} \mathrm{C}$ for 16-18 hours, and analyzed/ runned in 3\% agarose gel.

\section{Statistical Analysis}

The null hypothesis in this study was: "The allele frequency of H63D mutation in HFE gene is no different in NASH patients than controls in Turkish population". Additionally relation of H63D mutation with iron parameters and histopathological findings were sought. Following statistical tests and calculations were carried out:

In the comparison of two groups of numeric variables, the t-test was used for independent groups showing normal distribution, and the MannWhitney $U$ test for those not showing normal distribution. When comparing more than two groups, the Kruskal-Wallis analysis of variance was used. In case of significant difference, the multiple comparison test was used to determine the group(s) that created the difference. For qualitative variables, the Fisher's exact chisquare test was used in $2 \times 2$ polytomic tables when the anticipated frequency was less than 5, or otherwise, the continuity correction chi-square test was used. For multicelled tables, when the number of cells with anticipated frequency of $<5$ exceeded $20 \%$ of the total number of cells, the Fisher-Freeman-Holton test was used. The significance of the difference in H63D mutation between NASH patients and the control group was analyzed by the universe ratio significance test; the association between two numeric variables was examined by correlation analysis.

Statistical analyses were performed by the SPSS (ver. 11.5) and StatExact (ver. 3) software packages. The level of significance was set at $\mathrm{p}<0.05$. All the values shown on the tables are means and medians for numeric variables with or without normal distribution, respectively.

\section{RESULTS}

\section{Demographics and Laboratory Characteristics}

Of 32 patients with a clinical, laboratory and pathological diagnosis of NASH, $25(78 \%)$ were asymptomatic. The median age of patients was 45 years (ranged between 18-69 years) and 18 $(56 \%)$ were male (Table 1$)$. The median BMI was $28.1 \mathrm{~kg} / \mathrm{m}^{2}$ (ranged between 20.3-35.3 $\mathrm{kg} / \mathrm{m}^{2}$ ). Thirty seven percent of the patients had BMI $\geq 30 \mathrm{~kg} / \mathrm{m}^{2}$ and $66 \%$ had WHR $\geq 0$.9. Those patients with $\mathrm{BMI} \geq 30$ $\mathrm{kg} / \mathrm{m}^{2}$ had larger waist and hip circumferences and higher 2-hour blood glucose level $(p=0.003$, $\mathrm{p}=0.000$, and $\mathrm{p}=0.048$, respectively).
Median ALT level was $80 \mathrm{U} / \mathrm{L}$. When patients were grouped according median ALT level, patients with ALT $>80 \mathrm{U} / \mathrm{L}$ had greater BMI ( $p=0.036)$, weight $(p=0.01)$, waist circumference $(p=0.02)$ and hip circumference $(\mathrm{p}=0.008)$.

The rate of having hypertension, hypercholesterolemia $(>200 \mathrm{mg} / \mathrm{dL})$, hypertriglyceridemia $(\geq 200 \mathrm{mg} / \mathrm{dL})$, low HDL levels $(<35 \mathrm{mg} / \mathrm{dL})$, LDL elevation $(\geq 130 \mathrm{mg} / \mathrm{dL}) \quad$ were respectively $25 \%, 56 \%, 28 \%, 3 \%$ and $47 \%$.

Patients with IGT had greater waist $(p=0.03)$ and hip circumference $(p=0.03), B M I(p=0.01)$ and fasting glucose $(p=0.007)$. HOMA resistance was investigated in 28 of the 32 patients and median HOMA value was 2.7 (ranged between 0.3-5.1). HOMA $>3$ defining insulin resistance was $39 \%$; $50 \%$ in males and $25 \%$ in females. TS, tissue iron parameters (HIC, HII) and H63D mutation were not correlated with fasting glucose, 2hour blood glucose or HOMA.

Ferritin, HIC, HII levels were statistically higher in males than in females $(\mathrm{p}=0.001, \mathrm{p}=0.02$, and $\mathrm{p}=0.01$, respectively). All the patients had ferritin levels within normal limits and the median was $102 \mathrm{ng} / \mathrm{mL}$. The median TS was $28.4 \%$ (ranged between7-68\%). Two patients had TS $45 \%$ and $68 \%$. These patients respectively had ferritin 143 and 112 ng/dL, HIC 1566 and $165 \mu \mathrm{g} / \mathrm{g}$, HII 0.6 and 0.05 . The median HIC was $1535 \mu \mathrm{g} / \mathrm{g}$ (ranged between 109- 7005 $\mu \mathrm{g} / \mathrm{g})$. When HIC $\geq 1600 \mu \mathrm{g} / \mathrm{g}$ were used for diagnos is of iron overload it was present in $41 \%(12 / 29)$ of patients. Although the mean ferritin levels were higher in iron-overloaded patients $(132.1 \pm 69.8 \mathrm{ng} / \mathrm{ml}$ vs. 81.1 $\pm 65.9 \mathrm{ng} / \mathrm{ml}, \mathrm{p}=0.043)$, there was no statistically significant difference for ALT, TS between the group with or without iron overload ( $p>0.05)$. Two patients out of 29 had HII $>1.9$. These patients had HII of 2.46 and 3.79 , HIC of 2484 and $7005 \mu \mathrm{g} / \mathrm{g}$, TS of $33 \%$ and $31 \%$, ferritin levels of 203 and $180 \mathrm{ng} / \mathrm{ml}$, respectively. Their grade iron staining disputed a diagnosis of $\mathrm{HH}$. 
Table 1: Characteristics of Patients According to Sex.

\begin{tabular}{|c|c|c|c|c|}
\hline & $\begin{array}{l}\text { All patients } \\
(n=32)\end{array}$ & $\begin{array}{l}\text { Men } \\
(n=18)\end{array}$ & $\begin{array}{l}\text { Women } \\
(n=14)\end{array}$ & $\mathbf{p}^{+}$ \\
\hline Age (yr) & $45(18-69)$ & $42(18-69)$ & $51(40-64)$ & 0.02 \\
\hline Height $(\mathrm{cm})$ & $164(145-185)$ & $170(163-185)$ & $155(145-165)$ & 0.001 \\
\hline Weight (kg) & $76(56-112)$ & $81(56-112)$ & $69(58-86)$ & 0.003 \\
\hline $\begin{array}{l}\text { Body mass indeks }\left(\mathbf{k g} / \mathbf{m}^{2}\right) \\
<25 \mathrm{n}(\%) \\
25-29 \\
30-34 \\
\geq 35\end{array}$ & $\begin{array}{l}28.1(20.3-35.3) \\
5(16 \%) \\
15(47 \%) \\
11(34 \%) \\
1(3 \%)\end{array}$ & $27.9(20.3-33.8)$ & $28.4(25.1-35.3)$ & $>0.05$ \\
\hline $\begin{array}{l}\text { Waist hip ratio } \\
\text { WHR } \geq 0.9\end{array}$ & $0.91(0.81-1.05)$ & $\begin{array}{l}0.93(0.85-1.05) \\
15(83 \%)\end{array}$ & $\begin{array}{l}0.88(0.8-1.0) \\
6(42 \%)\end{array}$ & 0.01 \\
\hline CRP & $0.55(0.2-3)$ & $0.31(0.2-3.0)$ & $0.36(0.2-1.5)$ & $>0.05$ \\
\hline ALT (U/L) & $80(42-207)$ & $74(53-207)$ & $66(42-102)$ & $>0.05$ \\
\hline AST (U/L) & $50(26-112)$ & $41(31-112)$ & $44(26-98)$ & $>0.05$ \\
\hline AST/ALT & $0.65(0.33-1.29)$ & $0.53(0.33-1.1)$ & $0.67(0.4-1.2)$ & $>0.05$ \\
\hline Alkaline phosphatase (IU/L) & $269(70-616)$ & $264(70-433)$ & $270(167-616)$ & $>0.05$ \\
\hline Y-GT (IU/L) & $97(21-345)$ & $55(25-294)$ & $85(21-345)$ & $>0.05$ \\
\hline Bilirubin (mg/dl) & $0.64(0.1-1.6)$ & $0.68(0.1-1.6)$ & $0.59(0.2-1.2)$ & $>0.05$ \\
\hline Albumin & $4.4(3.7-5)$ & $4.5(4.2-5)$ & $4.3(3.7-4.8)$ & 0.03 \\
\hline $\begin{array}{l}\text { Fasting glucose (mg/dL) } \\
\text { IFG } n(\%)\end{array}$ & $\begin{array}{l}93(46-124) \\
5(16 \%)\end{array}$ & $94(45-120)$ & $92(46-124)$ & $>0.05$ \\
\hline Fasting insulin (IU/ml) & $11.8(2.8-23.0)$ & $12.6(2.8-20.8)$ & $10.7(3.4-23.0)$ & $>0.05$ \\
\hline Fasting C peptide (ng/ml) & $3.1(1.1-6.5)$ & $3.3(1.2-6.5)$ & 2.8 (1.1-4.6) & $>0.05$ \\
\hline HOMA score>3 & $2.7(0.3-5.1)$ & $3.0(0.7-5.1)$ & $2.3(0.4-5.0)$ & $>0.05$ \\
\hline Triglyceride (mg/dL) & $155(64-439)$ & $119(64-439)$ & $137(64-284)$ & $>0.05$ \\
\hline $\mathrm{HDL}(\mathrm{mg} / \mathrm{dL})$ & $55(30-126)$ & $47(30-126)$ & $57(42-84)$ & $>0.05$ \\
\hline LDL(mg/dL) & $124(43-208)$ & $113(43-166)$ & $138(52-208)$ & $>0.05$ \\
\hline Cholesterol (mg/dL) & $205(119-310)$ & $192(119-256)$ & $222(134-310)$ & 0.04 \\
\hline $\begin{array}{l}\text { Transferrin saturation }(\%) \text { TS } \geq 45 \mathrm{n} \% \\
\text { Serum ferritin (30-300 ng/ml) } \\
\text { HIC ( } \mu \text { g /g dry) } \\
\geq 1600 \mu \mathrm{g} / \mathrm{g} \mathrm{n}(\%) \\
\text { HII } \\
<1.1 \\
1.1-1.9 \\
>1.9\end{array}$ & $\begin{array}{l}28(7-68) \\
2(6 \%) \\
102(3-243) \\
1535(109-7005) \\
12(\% 41) \\
0.7(0.05-3.79) \\
23(79 \%)^{*} \\
4(14 \%)^{*} \\
2(7 \%)^{*}\end{array}$ & $\begin{array}{l}27(9-39) \\
137(26-243) \\
1794(320-7005) \\
9(50 \%) \\
0.69(0.15-3.8) \\
10^{*} \\
4^{*} \\
2^{*}\end{array}$ & $\begin{array}{l}29(7-68) \\
- \\
58(3-143) \\
841(110-1896) \\
3(21 \%) \\
0.30(0.05-0.6) \\
13^{*} \\
0^{*} \\
0^{*}\end{array}$ & $\begin{array}{l}>0.05 \\
- \\
0.001 \\
0.02 \\
0.01\end{array}$ \\
\hline
\end{tabular}

tmen vs.women. Abbreviations used: ALT, alanine aminotransferase; AST, aspartate aminotransferase; $\Upsilon$-GT, gama glutamyl transpeptidase; TS, transferin saturation; $\mathrm{HIC}$, hepatic iron concentration; HII, hepatic iron indeks; IFG, impaired fasting glycemia; IGT, impaired glucose tolerance; HOMA, homeostasis model assessment; HDL, high-density lipoprotein; LDL, low-density lipoprotein. (All the values shown on the tables are means and medians for numeric variables with or without normal distribution, respectively)

\section{Histopathological Findings}

Patients' pathological findings were as summarized in Table 2. Most of the patients have mild portal inflammation $(81 \%)$, macrovesiculer steatosis $\quad(66 \%)$, ballooning degeneration $(92 \%)$ and grade 1 necroinflamation $(44 \%)$ and fibrosis $(69 \%)$. Overall $30(94 \%)$ patients were Class 3 or 4 NAFLD on liver biopsy.

Patients with steatosis of $\geq 33 \%$, mild to moderate portal inflammation and
Grade 3 necroinflammatory score had higher ALT levels $(\mathrm{p}=0.017$, $\mathrm{p}=0.04$ and $\mathrm{p}=0.05$, respectively). TG levels were higher in patients with macrovesicular steatosis compared to those with microvesicular steatosis $(164 \pm 83.1$ $\mathrm{mg} / \mathrm{Dl}$ vs. $84.5 \pm 23.3 \mathrm{mg} / \mathrm{dL}$; $\mathrm{p}=0.005)$. Baseline $\mathrm{C}$-peptide values was higher in patients with steatosis $\geq 33 \%$ compared to those with steatosis $<33 \% \quad(p=0.047)$. Patients with mixed type steatosis had higher HOMA resistance compared to those with macrovesicular steatosis $(3.35$ vs. $2.4, \mathrm{p}=0.035)$.

2-hour blood sugar levels were higher $(128-105 \mathrm{mg} / \mathrm{dl})$ in Stage $\geq 2$ patients than in Stage 1 patients $(\mathrm{p}=0.05)$, and also higher in Class 4 patients than in Class $\leq 3$ patients $(p=0.05)$. Stage $\geq 2$ patients showed higher levels/values of ALT (73-68IU/L), AST (5547U/L), triglyceride $(172-146 \mathrm{mg} / \mathrm{dl})$, height $(166-163 \mathrm{~cm})$, weight $(75,5-$ $74,5 \mathrm{~kg})$, fasting blood glucose $(94-92$ $\mathrm{mg} / \mathrm{dl}), 2^{\text {nd }}$ hour glucose $(118-103$ $\mathrm{mg} / \mathrm{dl})$, fasting $\mathrm{C}$ peptide (3,3- 
3,0ng/ml), HIC (1854-1240 $\mu \mathrm{g} / \mathrm{g})$, HII $(0,55-0,43)$ when compared to Stage 1 patients; that did not reach statistical significance. No significant difference was found in sex, age, TS and ferritin values between Stage 1 and Stage $\geq 2$ patients ( $p>0.05$ ).

There was no correlation between patients' histopathological findings (fibrosis stage, grade, portal inflammation, steatosis grade and class) and serum and tissue iron parameters (ferritin, TS, HIC, and HII) although, a $41.7 \%$ of patients with $\mathrm{HIC} \geq 1600 \mu \mathrm{g} / \mathrm{g}$ were Stage $\geq 2$ (Figure 1). There was Stage 1 and 2 iron staining in $23(72 \%)$ and $9(28 \%)$ patients whereas Stage 3 or Stage 4 staining were not detected.

\section{H63D Mutation}

H63D mutation was tested in 30 patients. Thirteen of $30 \quad(43 \%)$ patients had H63D mutation; 12 $(40 \%)$ heterozygote and 1 (3\%) homozygote (Table 3).

In patients with NASH, H63D heterozygous allele frequency was $20 \%$ (12/60), H63D homozygous allele frequency was $3.3 \%(2 / 60)$, and total H63D allele frequency was $23.4 \%(14 / 60)$ (Table 3).

Twenty-four were found to be heterozygote for H63D mutation in the control group (20). No significant difference was found in the age of the control and study groups $(p>0.05)$. The allele frequency of H63D mutation for the control group was $21.05 \%$ (24/114) (20). There was no statistically significant difference between H63D allele frequencies of patients with NASH $(23.4 \%)$ and of the control group $(21.05 \%)$, consisting of blood bank donors representing the healthy Turkish population $(\mathrm{p}=0.29)$ (Table 4).

When we look to BMI> $25 \mathrm{~kg} / \mathrm{m}^{2}$ status, there was no significant difference between H63D mutation positive (homozygote and heterozygote) and negative (normal) patients (H63D positive vs. negative: $92 \%$ vs. $82 \% ; \mathrm{p}>0.05)$. Waist circumference $>$
$110 \mathrm{~cm}$, hip circumference $>100 \mathrm{~cm}$, waist-hip ratio $>0.9$ ratios were $23 \%$, $90 \%$ and $62 \%$ for H63D mutation positive patients and 29\%, 80\% and $70 \%$ for H63D mutation negative

patients; respectively ( $\mathrm{p}>0.05$ ). Among H63D mutation positive patients, $8 \%$ had fasting blood glucose $>110 \mathrm{mg} / \mathrm{dl}, 20 \%$ had $2^{\text {nd }}$ hour blood glucose $>140 \mathrm{mg} / \mathrm{dl}$.

Table 2: Histopathological Findings in Liver Biopsies.

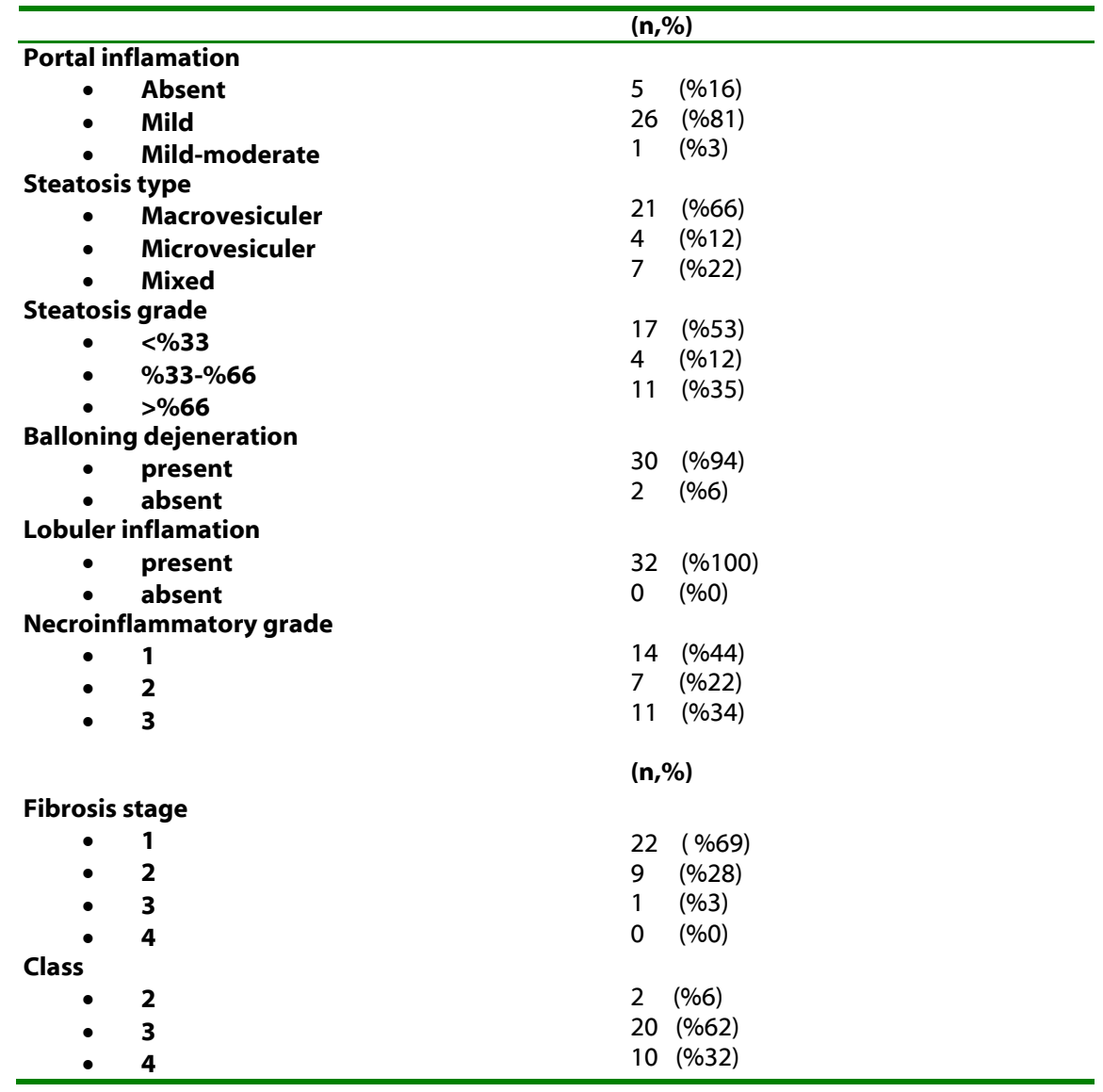

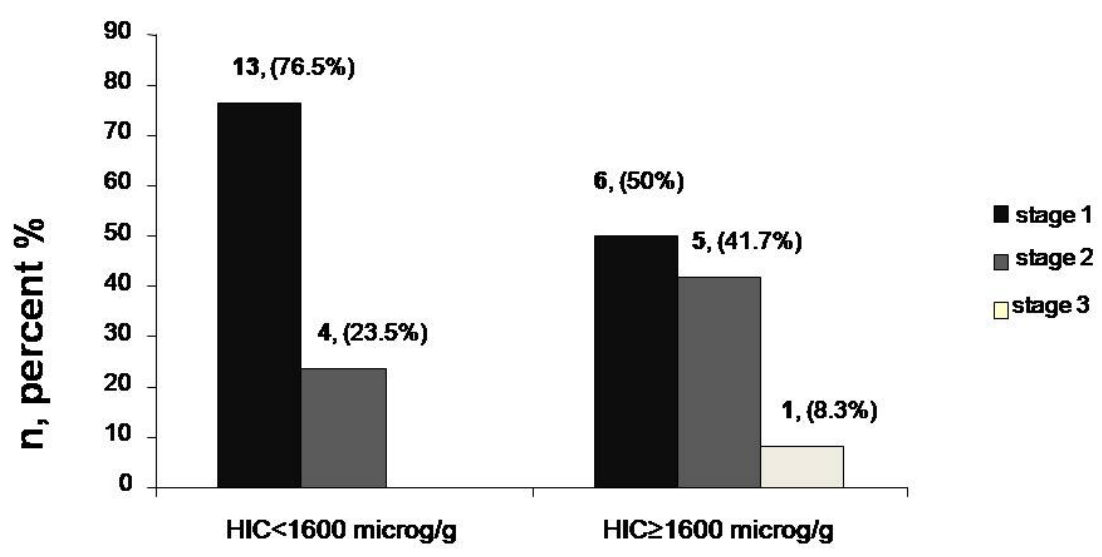

Hepatic Iron Concentration (HIC)

Figure 1: Distribution of Stage of NASH According to Hepatic Iron Concentrations 
These rates were $17.6 \%$ and $20 \%$ for fasting blood glucose and $2^{\text {nd }}$ hour blood glucose for mutation negative patients, and there were no significant difference between two groups. Similarly there was no significant difference for fasting insulin, fasting $\mathrm{C}$ peptide, HOMA values between two groups.
The patients with H63D mutation had TS, ferritin, HIC and HII values within normal limits. Only one of the 13 patients $(7 \%)$ in the group with mutations, and likewise, only one of the 17 patients without mutations $(6 \%)$ had $\mathrm{TS} \geq 45 \%$ ( $>>0.05)$. There was no statistically significant relationship between H63D mutation and histopathological findings (fibrosis stage, grade, portal inflammation, steatosis grade and class). Although 1 patient with H63D mutation had Stage 3 NAFLD, there was no statistical significance $(p=0.7)$ (Figure 2).

Table 3: Distribution of H63D Mutations

\begin{tabular}{|l|l|l|l|}
\hline H63D mutation & Men $(\mathbf{n}, \%)$ & Women (n,\%) & All patients (n,\%) \\
\hline H63D-/-(normal) & $11(\% 65)$ & $6(\% 35)$ & $17(\% 100)$ \\
H63D-/+(heterozygote) & $4(\% 33)$ & $8(\% 67)$ & $12(\% 100)$ \\
H63D+/+(homozygote) & $1(\% 100)$ & $0(\% 0)$ & $1(\% 100)$ \\
\hline
\end{tabular}

Table 4: The Distribution of H63D Mutations in NASH and Control Group

\begin{tabular}{|l|l|l|l|l|l|}
\hline & H63D-I- & H63D+l- & H63D+/+ & Total & P \\
\hline NASH (n \%) & $17(56.6)$ & $12(40)$ & $1(3,4)$ & 30 & 0.29 \\
\cline { 1 - 3 } & $33(57.9)$ & $24(42.1)$ & 0 & 57 & \\
\hline
\end{tabular}

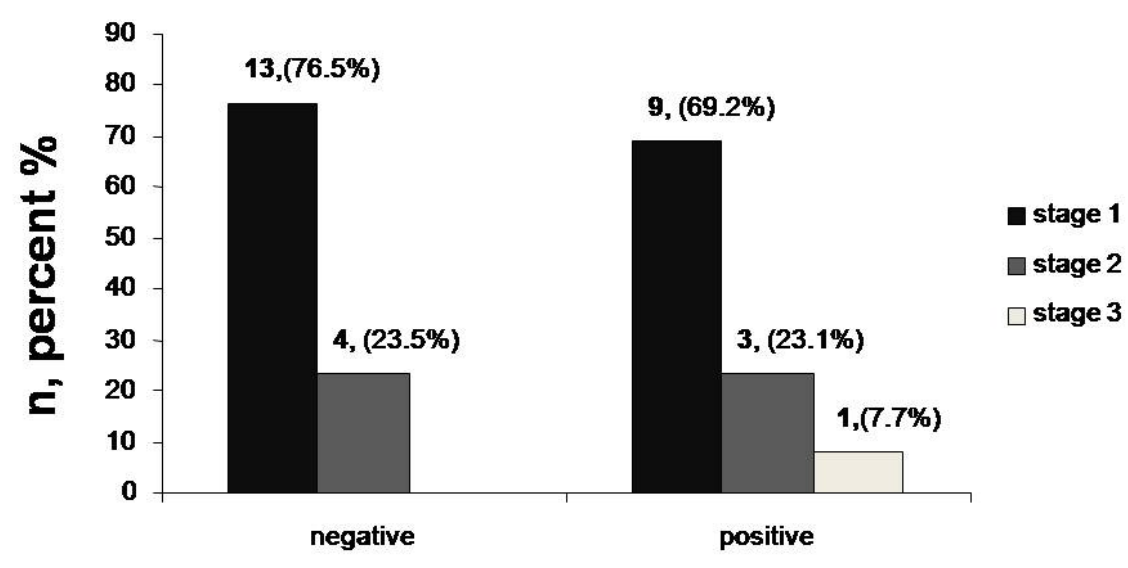

\section{H63D Mutation}

Figure 2: Stage of NASH According to H63D Mutation

\section{DISCUSSION}

The present study had revealed that H63D mutation allele frequency in patients with $\mathrm{NASH}$ is similar to the general population. Although there was a slight degree of iron accumulation in NASH, there was no statistical correlation with either H63D mutation or liver fibrosis. Furthermore insulin resistance was related with histopathologic and antropometric parameters, but not with iron parameters in NASH patients.
The obesity prevalence among NASH patients can be as high as $40-100 \%$, but NASH also has been reported in individuals with normal BMI $(23,24)$. The central obesity and insulin resistance are established risk factors for fatty liver (25). In our study, 37\% of patients had BMI $\geq 30 \mathrm{~kg} / \mathrm{m}^{2}$, thus accepted as obese.

Insulin resistance also has an important role in the pathogenesis of NASH. $\mathrm{DM}$ or glucose intolerance is observed in $30-50 \%$ of patients with NASH. Although diabetic patients were excluded from present study, $16 \%, 22 \%$ and $39 \%$ of our patients had IFG, IGT and insulin resistance (HOMA>3), respectively. Furthermore the rates of HT, obese, central obesity, hypercholesterolemia and hypertriglyceridemia were respectively $25 \%, 37 \%, 66 \%, 56 \%$ and $28 \%$. These findings support the close correlation between NASH and metabolic syndrome. Since histopathological severity of steatosis and the degree of inflammation were positively correlated with weight, but 
not with obesity, we suggested that the insulin resistance is related to obesity, whereas steatosis and inflammation are more corelated with increased total body weight. The higher prevalence of IGT in patients with Stage $\geq 2$ fibrosis suggest a correlation between fibrosis and insulin resistance.

The literature shows that not only ALT levels are not correlated with steatosis and stage, but also elevated ALT levels and AST/ALT ratio of $>1$ are correlated with higher histological stage and fibrosis in NASH (26). In our study, the patients with elevated ALT had statistical increase in portal inflammation, steatosis and inflammation, but no enhancement in liver fibrosis. There was a statistically significant increase in BMI, central obesity, waist circumference and hip circumference in patients with $\mathrm{ALT} \geq 80 \mathrm{IU} / \mathrm{mL}$.

The previous studies revealed that the allele frequencies of $\mathrm{C} 282 \mathrm{Y}$ and H63D mutations are $0 \%$ and $21.05 \%$ among Turkish healthy blood bank donors $(13,27)$. On the other hand, a subsequent study carried out in Turkey detected C282Y mutataions in Turkish patients. (28). Because of absence of C282Y mutation in our population while we were conducting this study, we analyzed here only H63D mutation and its allele frequency was $23.4 \%$ in patients with NASH. The allele frequency was statistically similar with healthy blood donors $(p=0.29)$. In the literature on HFE mutations in NASH patients, George et al.(29) reported an increase in the frequency of $\mathrm{C} 282 \mathrm{Y}$ mutation (31\%) but a similar rate of H63D mutation with the general population, while Bonkovsky et al.(30) reported higher frequency of $\mathrm{C} 282 \mathrm{Y}$ and H63D heterozygous mutations (61.1\% and 38\%, respectively). Duseja et al.(31) showed absence of
C282Y mutation and 25\% H63D heterozygosity rate in Asian Indians with NASH. Chitturi et al. (32) reported increased frequency of C282Y mutation. Zamin et al. (33) observed $55.2 \%$ rate of $\mathrm{C} 282 \mathrm{Y}$ and H63D mutations in their patients Neri et al. (34) showed that there was no increase in C282Y and H63D heterozygosyties. In a study from Korea, neither C282Y nor S65C gene mutations were detected, however prevalence of H63D mutation was significantly higher in NASH group than controls (34). However the recent metaanalysis by Hernaez et al. (35) including 2542 studies (2287 cases, 4275 controls from Caucasian race) revealed no significant association between HFE genetic variants and NASH .

In patients with $\mathrm{NASH}$, ferritin levels are increased in $21-60 \%$ of patients, and TS values are increased in $5-22 \%$ $(6,11,36)$. Ferritin is a component of IRS. The iron overload is a component of IRS or of insulin resistance-associated hepatic iron overload (IRHIO) as defined by Mendler et al. (37). The insulin resistance is held responsible for persistent hyperferritinemia in NASH patients with normal TS and elevated ferritin levels. The abnormalities of iron parameters in NASH are secondary phenomena to the insulin resistance syndrome similar to patients with nonhereditary hemochromatosis. In our study, 2 patients $(6 \%)$ had increased serum TS values of over $45 \%$, but all ferritin levels were within normal limits. Although there were insulin resistance and mild iron overload, we could not establish a relationship between iron them. Furthermore the serum ferritin, TS, HIC and HII values were similar in NASH patients with or without H63D mutations.
The publications regarding hepatic iron load in NASH are conflicting. George et al.(29) determined iron overload in $23 \%$ of patients with NASH . Contrary to that Younossi et al.(12), Bonkovsky et al.(30), and Duseja et al.(31) did not demonstrate marked iron overload in patients with NASH. Also Neri et al.(10), Bugianesia et al.(11), Chitturi et al (32)and Valenti et al. (38) did not demonstrate an association between HFE mutation, iron overload and fibrosis .

In our study, all patients had Grade 1-2 normal iron staining levels in consistence with previous literature $(19,38)$. The presence of H63D mutation was not associated with iron overload neither in serum nor in liver of NASH patients. Although the histopathological findings (Grade, Stage and Class) of patients with H63D mutations were more enhanced than the patients without mutations, the differences were not statistically significant.

The allele frequency of minor mutation of HFE gene; namely $\mathrm{H} 63 \mathrm{D}$ in patients with NASH was similar to Turkish population. In spite of mild iron accumulation in patients with $\mathrm{NASH}$, there was no correlation between H63D mutation and fibrosis (15). The insulin resistance was related with fibrosis, but not with iron load or H63D mutation. The data of this study confirmed the previous literature showing that H63D mutation plays a minor role in pathogenesis of NASH through the insulin resistance caused by mild iron loading in the liver.

Acknowledgement: The authors thank Dr. Erdem Karabulut for expert assistance in statistical analysis of the manuscript. 


\section{REFERENCES}

1. Santos L, Molina EG, Jeffers L. Prevalence of nonalcoholic steatohepatitis among ethnic groups. Gastroenterology 2001;120 Suppl 1:630.

2. Tominaga K, Kurata JH, Chen YK, et al. Prevalence of fatty liver in Japanese children and relationship to obesity. An epidemiological ultrasonographic survey. Dig Dis Sci 1995;40:2002-2009.

3. Baldridge A, Perez-Atayde A, GraemeCook F, et al. Idiopathic steatohepatitis in childhood: A multicenter retrospective study. J Pediatr 1995;127:700-704.

4. Powell EE, Cooksley WG, Hanson R, et al. The natural history of nonalcoholic steatohepatitis: a follow-up study of fortytwo patients for up to 21 years. Hepatology 1990;11:74-80.

5. Kumar KS, Malet PF. Nonalcoholic Steatohepatitis. Mayo Clin Proc 2000;75:733-739.

6. Bacon BR, Farahvash MJ, Janney CG, et al. Nonalcoholic steatohepatitis: an expanded clinical entity. Gastroenterology 1994;107:1103-1109

7. Sreppan CM, Bailey ST, Bhat S, et al. The hormone resistin links obesity to diabetes. Nature 2001;409:307-312.

8. Marchesini G, Brizi M, Morselli-Labate AM, et al.. Association of nonalcoholic fatty liver disease with insulin resistance. Am J Med 1999;107:450-455.

9. Ikai E, Ishizaki M, Suzuki $Y$, et al. Association between hepatic steatosis, insulin resistance and hyperinsulinaemia as related to hypertension in alcohol consumers and obese people. J Hum Hypertens 1995;9:101-105.

10. Neri S, Pulvirenti D, Santo S, et al. The HFE gene heterozygosis H63D: a cofactor for liver damage in patients with steatohepatitis? Epidemiological and clinical considerations. Intern Med J 2008;38(4):254-258.

11. Bugianesi E, Manzini P, D'Antico S, et al. Relative contribution of iron burden, HFE mutations, and insulin resistance tofibrosis in nonalcoholic fatty liver. Hepatology 2004;39:179-187.

12. Younossi ZM, Gramlich T, Bacon BR, et al. Hepatic iron and nonalcoholic fatty liver disease. Hepatology 1999;30:847-850.

13. Şimşek $H$, Sümer $H$, Yılmaz E, et al. Frequency of HFE Mutations among Turkish Blood Donors According To Transferrin Saturation. Genotype screening for hereditary hemochromatosis among voluntary blood donors in Turkey. J Clin Gastroenterol 2004;38:671-675.
14. Simsek H, Balaban YH, Yilmaz E, et al. Mutations of the HFE gene among Turkish hereditary hemochromatosis patients. Ann Hematol 2005;84:646-649.

15. Simsek $H$, Balaban $Y H$, Sümer $H$, et al. HFE mutations analysis of Turkish patients with nonalcoholic steatohepatitis. Dig Dis Sci. 2006 ;51:1723-1724.

16. World Health Organization. Definition, diagnosis and classification of diabetes mellitus and its complications-Part 1: Diagnosis and classification of diabetes mellitus. Geneva: World Health Organiza tion; 1999:20-21.

17. Haffner MS, Miettinen H, Stern MP. The homeostasis model in the san Antonio Heart Study. Diabetes Care 1997;20:10871092.

18. Marchesini G, Bugianesi E, Forlani G, et al. Nonalcoholic fatty liver, steatohepatitis, and the metabolic syndrome.Hepatology. 2003 Apr;37(4):917-23.

19. Brunt EM, Janney CG, Di Bisceglie AM, et al. Non-alcoholic steatohepatitis: a proposal for grading and staging the histologic lesions. Am J Gastroenterol 1999;94:246774.

20. Roderick R.M., MacSween R.N.M., Antony P.P., Scheuer P.J., editors. Pathology of the liver. 2 nd ed..Edinburgh: Churcill Livingstone; 1987.p.185.

21. Bassett ML, Halliday JW, Powell LW. Value of hepatic iron measurements in early hemochromatosis and determination of the critical iron level associated with fibrosis. Hepatology1986; 6:24.

22. Bacon BR, Britton RS. Hemochromatosis. Sleisenger and Fordtran's Gastrointestinal and Liver Disease (Ed. M.H. Sleisenger, B.F. Scharschmidt ve M Feldman)8th Edition W.B. Saunders Company Press, USA, 2006;1589-1599.

23. Pagano G, Pacini G, Musso G, et al. Nonalcoholic steatohepatitis, insulin resistance, and metabolic syndrome: further evidence for an etiologic association. Hepatology 2002;35:367-372.

24. Chitturi S, Abeygunasekera S, Farrell GC, et al. NASH and insulin resistance: insulin hypersecretion and specific association with the insulin resistance syndrome. Hepatology 2002;35:373-379.

25. Kral JG, Schaffner F, Pierson RN Jr, et al Body fat topography as an independent predictor of fatty liver. Metabolism 1993;42:548-551.

26. Angulo P, Keech JC, Batts KP, et al. Independent predictors of liver fibrosis in patients with nonalcoholic steatohepatitis. Hepatology 1999;30:1356-1362.
27. Barut G, Balci H, Bozdayi M, ve ark. Screening for iron overload in the Turkish population. Dig Dis 2003; 21:279-285.

28. Yönal Ö, Hatırnaz O, Akyüz F, ve ark. HFE gene mutation, chronic liver disease, and iron overload In Turkey. Dig Dis Sci 2007;52:3298-3302.

29. George DK, Goldwurm S, Macdonald GA, et al. Increased hepatic iron stores on non alcoholic steatohepatitis are associated with the hemochromatosis mutation and increased liver damage. Gastroenterology 1998;114:311-318.

30. Bonkovsky HL, Jawaid Q, Tortorelli K, et al. Nonalcoholic steatohepatitis and iron: increased prevalanceof mutations of the HFE gene in nonalcoholic steatohepatitis. J Hepatol 1999;31:421-429.

31. Duseja A, Das R, Nanda $M$, et al. Nonalcoholic steatohepatitis in Asian Indians is neither associated with iron overload nor with HFE gene mutations. World J Gastroenterol 2005;21;11:393-395.

32. Chitturi S, Weltman M, Farrell GC, et al. HFE mutations, hepatic iron, and fibrosis: ethnic-specific association of NASH with C282Y but not with fibrotic severity. Hepatology 2002;36:142-149.

33. Zamin I Jr, Mattos AA, Mattos AZ, et al. Prevalence of the hemochromatosis gene mutation in patients with nonalcoholic steatohepatitis and correlation with degree of liver fibrosis.Arq Gastroenterol 2006;43:224-228.

34. Lee SH, Jeong SH, Lee $\mathrm{D}$, et al. An epidemiologic study on the incidence and significance of HFE mutations in a Korean cohort with nonalcoholic fatty liver disease. J Clin Gastroenterol. 2010;44:154-161.

35. Herneaz R, Yeung E, Clark JM, et al. Hemochromatosis gene and nonalcoholic fatty liver disease: a systematic rewiew and meta-analysis. J.Hepatol 2011;55: 1079 1085.

36. Sanyal AJ, MBBS. Nonalcoholic steatohepatitis. Clinical perspectives in Gastroenterology 2000;129-139.

37. Moirand R, Mendler MH, Guillygomarc'h A.,et al. Non-alcoholic steatohepatitis with iron: part of insulin resistance-associated hepatic iron overload? J Hepatol 2000;33:1024-1026.

38. Valenti L, Fracanzani AL, Bugianesi E, et al. HFE genotype, parenchymal iron accumulation and liver fibrosis in patients with nonalcoholic fatty liver disesase. Gastroenterology. 2010;138:905-912. 